\title{
CREATION OF YOUNG ENTREPRENEURS AS RESOURCES OF ECONOMIC DEVELOPMENT AND ALLEVIATION OF POVERTY IN MUSLIM COUNTRIES: AN ISLAMIC APPROACH
}

\author{
Chaibou Issoufou
}

Department of Economics and Law, Universiti Kuala Lumpur Business School, Malaysia.

Email: Issoufou@unikl.edu.my

\author{
Article History: Received on $21^{\text {st }}$ August 2019, Revised on $29^{\text {th }}$ September 2019, Published on $05^{\text {th }}$ November 2019
}

\begin{abstract}
Purpose of Study: This paper aims to examine the importance of entrepreneurship and the role of young entrepreneurs in economic development. The paper explores the vital role that entrepreneurship can play in boosting economics of a country. This is because creating youth on entrepreneurial skills can be used as resources of economic development and alleviation of poverty in a country. The paper examines how Muslim youth can be created and trained as resources of development of economics and prevention of poverty in Muslim countries.
\end{abstract}

Methodology: The paper adopts qualitative research methodology to collect and analyze data on the topic in hand. This methodology is used to discuss the effect of training on young entrepreneurs and how it creates them as resources of economic growth and improvement of scarcity in a country.

Results: It finds in this paper that young entrepreneurs are the most crucial instruments that can be utilized to enhance economics of a country and eliminate poverty in the society. This is because young generation is the most important generation that can be taken as a tool and resource to develop economics of a country and alleviate poverty in the society at large.

Implications/Applications: Entrepreneurship plays a crucial role in economic development and creation of young entrepreneurs can be used as resources of economic enhancement as well as job opportunity for Muslim youth. The paper suggests to have empirical research in order to have a clear picture on creation of young entrepreneurs and effect of training them on entrepreneurship as resources of economic development and alleviation of poverty in Muslim countries.

Keywords: entrepreneurs, Islamic law, training, poverty, muslim youth.

\section{INTRODUCTION}

Islam encourages Muslim youth to be entrepreneurs since the era of Prophet Salla allahu alaihi wassalam (S.A.W). T0first young Muslim entrepreneur was Uthman bin afan. When the Prophet s.a.w. created a brotherhood between him and sa'ad bin Rabi'i the latter divided his wealth into two parts between him and Uthman but the former refused to take his part and told his brother in Islam (Sa'ad), may Allah bless your wealth, show me the market of al-Madinah

I know how to sell and buy from there he was initiated and created his entrepreneurial skill and became successful entrepreneur in al-Madinah until now he has a bank account in of one the banks in al-Madinah al-Munawwarah, Saudi Arabia.

Islam invites all nations to entrepreneurship males and females, Islam does not encourage people to be dependent on others, indeed it encourages people to be independent and not rely on others. Islam urges a person to work hard in this world like he is going to live in it forever and work for hereafter like he is going to die tomorrow. Thus, in Islamic point of view a Muslim has to combine between this world and hereafter as both of them were created for him to live in prosperity and happiness in this world and get paradise in hereafter. Therefore, a young Muslim has to work hard in this world because in hereafter Allah Subhanahu wata'ala (S.W.T) will ask him about three things, one of them is his young generation how does he spend it in this world. This is because young generation is very important generation which a young Muslim has to be careful to utilize it in what is beneficial for him in both here and hereafter. Islam encourages young Muslim to take opportunity to use his young generation to serve his nation in general and particularly himself and other kin. Hence, young Muslim should train himself on entrepreneurship to be entrepreneur who is going to use his entrepreneurial skills to work for his country in order to develop the economy of the country and prevent poverty in the society. Islam as religion which can suit anytime and anywhere invites a young Muslim to be entrepreneur who will serve his nation. As a result, creation of young entrepreneurs is crucial element which can boost the economy and alleviate the poverty in Muslim countries.

\section{REVIEW OF LITERATURE}

Faizal et al. (2013) found that Islam urges Muslims to be entrepreneurs because entrepreneurship is one of the elements that can alter problems of economics of a country. Entrepreneurship is one of Islamic culture as Prophet Muhammad Sallahu alaihi wasssalam (S.A.W) and his companions have demonstrated it since early era of Islam. Islam invites Muslims to be creative entrepreneurs and dynamics. In this world many Muslims were successful entrepreneurs. The Prophet Muhammad (S.A.W) was entrepreneur before his prophetic mission who was successful in entrepreneurship. The entrepreneurship is one of the factors that can assist in alleviation of poverty and develop system of economics of a 
country. Thus, social entrepreneurship is the global phenomenon that can influence the society by applying creative ways to solve social problems. Current economic situation can only be minimized and solved by entrepreneurship activities. This is because entrepreneurship is new phenomenon that can decrease social problems and eliminate poverty in the society.

Gumusay (n.d) argued that Islam in mind is more obvious, and in market it is easy to utilize. Islamic entrepreneurship which is based on construction of marketing more than academic rigorous and theological appropriate. From Islamic law perspective, it is suggested to use specific terminology for entrepreneurship which involves both vigilance and comprehensive understanding of entrepreneurship. For the reason that Islam did not give any specific terminology to entrepreneurship. Islamic entrepreneurship is similar to Islamic economics and finance which refer to certain business activities in Islamic way.

Ullah et al. (2015) explain that entrepreneurship is a practice which is neither a science nor art. It is a new method of doing something which was done previously. Enhance, an entrepreneur is a person who takes the products and resources of economics from lower level to higher level with high profit. However, Hoque et al. (2014) argue that a country is poor because of its insufficient and unqualified entrepreneurs. This is because development of economics of a country is driven by the qualified entrepreneurs of the country.

From the above statement, one can say that there is a need to conduct a research on this topic in order to find out how to create qualified entrepreneurs who can be able to accelerate economic development of their countries. Davis (2013) contends that many academic writing on Islamic economics are in Arabic, Urdu and other languages which are not commonly spoken by non-Muslims writers. Therefore, Islamic entrepreneurship is lack of academic writing which is one of reasons that causes lack of understanding of Islamic entrepreneurship. This is because some Western writers are of view that Islam is not compatible with entrepreneurship. Based on that, one can say that there is a crucial need to conduct a research on this topic in hand, so that non-Muslim writers can understand Islamic entrepreneurship. For the reason that entrepreneurship and business activities are parts of Islam. As Islam encourages Muslims to involve in entrepreneurship and business venture in accordance with the principles of Islamic law. In Islam success is not assessed by the results of achievement but by the means to achieve the success (Adewale, 2016; Ambrose et al., 2016; Ametorwo, 2016; Amogechukwu and Unoma, 2017; Gisore and Jepchumba, 2017). In Islam the philosophy of entrepreneurship is based on the principles of Islamic law that derived from al-Qur'an and al-Sunnah of the Prophet (S.A.W). Entrepreneurship is not just to begin a business venture, it is more about the behaviours and achievement to the success. To develop and create the new goods and services there is a need for entrepreneurial abilities and qualities. In Islamic law perspective, entrepreneurship and management should be accepted by the society based on moral values. This moral view is derived from prohibition of riba and greedy in Islam. For this reason, entrepreneurship is crucial element for the development of economic in Muslim countries and societies at large (Bello and Aliyu, 2016; Bozorgian and Kanani, 2017; Aremu and Ediagbonya, 2018).

From the above literature, one can say that there is a need to conduct a research on the topic in hand in order to highlight the crucial role that entrepreneurship can play in the economic development of a country and find out how to create qualified entrepreneurs who can be able to accelerate economic development of their countries.

\section{METHODOLOGY OF STUDY}

The study adopts a qualitative research methodology approach wherein the theoretical framework of creation of young entrepreneurs as resources of economic development and alleviation of poverty in Muslim countries is approached through the collection of relevant data from literature such as textbooks, encyclopaedia, and articles in academic journals, seminars, conference papers, online databases and internet materials. This method of data collection is based on library research in order to examine and explore the issues relating to the topic in hand.

\section{SIGNIFICANCE OF ENTREPRENEURSHIP IN ISLAM}

Islam invites all Muslims to be entrepreneurs since its initial stage. Islam encourages Muslim youth to involve in entrepreneurship to be self-independent and provide job opportunity to others. This is because, Islam allowed Mudarabah, Musharakah and other commercial contracts which are carried out by those who have entrepreneurial skills to participate in the economic development. For example, Usman bin Affan was young entrepreneur who involved himself in entrepreneurship and was successful entrepreneur who served Islam and Muslims in many calamities. His charity fund was running from his era until now. Currently he has a charity bank account which is managed by government of Saudi Arabia to serve Muslims to alleviate poverty in the country. This can show the significance of entrepreneurship to be used as economic instrument to develop economics of a country and eliminate poverty in the society. Islam is system of life which Allah (S.W.T) has given to us to live in this world accordingly and get paradise in hereafter. In Islam there is no separation between economic system and religion of Islam. Entrepreneurship is integral part of Islam as Islam urges Muslim to be innovative and creative entrepreneurs. It was mentioned in the Hadith that the Prophet $(S . A . W)$ is reported to have said: "one cannot ever eat any food which is better than that is produced by his hands on" (AyukAko, 2017; Dierker et al., 2018; Donkor and Waek, 2018; Sokyna and Omayma, 2018). 
Islam has its characteristics and principles of entrepreneurship which are derived from al-Qur'an and al-Sunnah of the Prophet (S.A.W). These characteristics and guides are distinguished Muslimpreneurs from other entrepreneurs. This is because, Muslimpreneurs carry out their business activities based on faith and belief in Allah (S.W.T) which drive them to successful business activities. Muslimpreneurs conduct their entrepreneurial activities in order to fulfil their obligation in this world not to make profit only (Faizal et al., 2013; Abd et al., 2015; Essien et al., 2016; Gamba, 2017; Sandra and Vidya, 2018). Muslim's duty in business activities is not only to generate profit in this world but to get the blessing of Allah (S.W.T) in hereafter which is paradise. Thus, the concept of entrepreneurship in Islam is a business activity in which Muslim entrepreneurs are combined between here and hereafter. For the reason that Islam is system of life to be followed according to its principles and regulations which will be resulted by success in this world and the world after. Therefore, in Islam entrepreneurship is not to make profit only, but to produce goods and render services which are not involving in non halal activities. Islamic entrepreneur is a person who conducts his business activities in accordance with the principles of Islamic law. He does not indulge in any activity which is not advised by the teaching of al-Qur'an and al-Sunnah (Abdul and Che, 2011; Ramadani et al., 2015; Bugu and Yucheng, 2018; Bilal and Miriam, 2019). Entrepreneurship play a crucial role in Islam and economic development of a country particularly Muslim countries.

\section{CREATION OF YOUNG ENTREPRENEURS}

In Islam, Muslim youth are the most important generation which Islam takes it into consideration since its infancy. As the Prophet (S.A.W) is reported to have said: "a Muslim has to take opportunity to use his young generation in something that is beneficial for him before he is going to be old"

A country can train its youth to be entrepreneurs and provide entrepreneurial skills for them from the beginning in primary and secondary schools, and make this entrepreneurial training compulsory on the youth in their schools all over the country's education system in order to create them to be future (young) entrepreneurs who will use their entrepreneurial skills to develop economy of the country and create jobs opportunities for others. They also can train others who do not have entrepreneurial skills. This can accelerate economic development of the country and elimination of poverty in the society.

By training those youths on entrepreneurship from the primary and secondary schools. The child will be ready to be an entrepreneur even though government of the country is not able to provide job opportunity for him. There is no worry about his future, because of his entrepreneurial skills and training which were provided for him in his education system. He can create his own enterprise and business firm. This system of creation and training of youth can be used as resources for economic development in the Muslim countries especially in non-developed countries. This training can assist in the growth of sale products and development of new products as well as providing entrepreneurial skills for entrepreneurs. Training can help new entrepreneurs to run their business activities confidentially, because people are doubt to engage in business activities because of lack of experience and skill in the business area. Therefore, having entrepreneurial training as prerequisite for young entrepreneurs can encourage them to engage in entrepreneurship activities and boost their business activities smoothly. Those who are trained before entering in business activities are almost having confidentiality and necessary information in the area. This can distinguish them from those who do not have enough information on entrepreneurship as Allah (S.W.T) said in al-Qur'an: "did those who have knowledge are equal to those who do not have it". Those who have entrepreneurial skill and training are more successful entrepreneurs than those who do not have that entrepreneurial skill. As a result, by creating those young entrepreneurs in any country particularly Muslim countries the economics of the country can be developed faster. This is because the young citizens of the country are already prepared to be resources for the development of the economics of the country. Therefore, there is no worry about job opportunity in the country for future generation and economic development.

\section{DEVELOPMENT OF ECONOMICS AND ENTREPRENEURSHIP}

Islam encourages Muslims to be creative and innovative in their business activities as well as good in their business enterprise, because thousands of people may benefit from good business enterprise as initiative to create a good business enterprise can be considered as good deed in the eyes of Allah (S.W.T). In al-Qur'an Allah (S.W.T) said: "Those who do righteous deed shall have a reward unfailing" (al-Qur'an, 2:42). Muslim entrepreneur should have sufficient zeal, mental stamina and inspiration to initiate his business enterprise and accelerate economic development of his country. Indeed, Allah (S.W.T) has recommended Muslim to be creative and innovative for driving resources of economics as He (S.W.T) said in al-Qur'an: "When your prayer is over, spread over the earth and seek the bounty of Allah" (al-Qur'an, 62:10).

From the aforesaid, one can say that creation of young entrepreneurs can play a crucial role in economic development and mobilization of resources for economic growth in the Muslim countries as Islam encourages Muslim to work hard to live independently and not rely on others or wait fortune to come.

Islamic economics is still at its early stage particularly entrepreneurship in Islamic context. Therefore, understanding entrepreneurship and Islamic economics system is crucial part of economic system as entrepreneurial behaviours and Islamic economics have become part of conventional financial system (Davis, 2013; Elfakhani and Ahmed, 2013; Gümüsay, n.d.). In Islam a business man has to take the risk of business venture then he deserved the profit derived from the business. In entrepreneurship concept the main characteristic that can distinguish entrepreneurs from others is that entrepreneurs are willing to take risk and be creative in their personality and behaviours. This is because entrepreneurship 
enables them to participate in economic and job growth as well as creation of new business activity. Thus, entrepreneurship consists of activity and process involve creation of business activity. The person who is engaging in this business activity is entrepreneur who is thinking about how opportunity is realizing and condition of resources are accelerating. The main premise of an entrepreneur is to increase resources to high productive level of business activity. Hence, Muslim entrepreneurs should differentiate from non-Muslim entrepreneurs in their motives and goals. Muslim entrepreneurs are not allowed to engage in business activities which are not in accordance with the principles of Islamic law. They are only permitted and encouraged to involve in the business activities which are morally accepted by Islamic law.

From the above statement, one can say that entrepreneurship play a vital role in economic development of a country and creation of jobs opportunities for others. This can participate in alleviation of poverty in the country particularly Muslim countries in which entrepreneurship is still at its infancy stage.

\section{FINDINGS}

It was discovered in this study that creation of young entrepreneurs can play a crucial role in development of economics of Muslim countries and non-Muslim countries. In Islamic law perspective, entrepreneurship is highly encouraged to carry out. Islam urges Muslim youth to be entrepreneurs in order to participate in development of economy of the country. This is because entrepreneurship is one of the key elements that can be used to accelerate economy of a country and creation of jobs opportunities for others. The growth of economics of a country is based on its entrepreneurs particularly young entrepreneurs who are most important elements to be utilised to develop economy of the country and alleviation of poverty in the country especially Muslim countries which are having huge number of poor people because of lack of entrepreneurial skills for many people in the country particularly its youth who are the most crucial assets that can be used to increase products of the country to high quality which can be imported and exported to other countries. In addition, it was argued in the study that training Muslim youth on entrepreneurship can play a crucial role in development of economics and elimination of poverty in the country. Thus, young entrepreneurs are future generation and leaders of a country who are required to develop and accelerate economics of the country by using their experience and entrepreneurial skills that have been taken in their educational period.

\section{CONCLUSION}

Young entrepreneurs play a crucial role in development of economics of a country and alleviation of poverty. Those young people can be used a resources for acceleration of country's economy and wellbeing of society at large. Islam is a religion that urges Muslim youth to work hard in order to live in this world independently and not rely on others. This is because young generation has high consideration in Islamic law point of view. It is the most generation which a young person can take opportunity to use it in something that can benefit him in his future. Therefore, creation of young entrepreneurs can be considered as resources for economic development and prevention of poverty in Muslim countries and non-Muslim countries. This is because many Muslim countries are facing problems of unemployment and enterprise. For the reason that, their youth are not prepared and trained to become entrepreneurs who can participate in the development of economics of the countries and elimination of poverty in the societies. Furthermore, entrepreneurship is milestone of a country's economy acceleration which can increase productions of the country that can be imported and exported to enhance welfare of people in the country particularly its youth who are going to be future leaders of the country. The researcher suggested to have empirical research on the topic in hand in order to have clear picture on the theme.

\section{REFERENCES}

1. Abd, M.M.A., A. Shuhairimi and B. Azizan, 2015. Model on social entrepreneurship: Identify the research gap based on Islamic perspective. Journal of Holistic Student Development, 2(1).

2. Abdul, H.S. and Z.S. Che, 2011. Reconstructing entrepreneur's development based on al-Qur'an and al-Hadith. International Journal of Business and Social Science, 2(19).

3. Adewale, A.A., 2016. Change, customer satisfaction and competition: Issues from the strategic management context. International Journal of Economics, Business and Management Studies, 3(2): 55-66.

4. Ambrose, A.O., I.E. Etim and F.M. Enagu, 2016. The role of community development programmes in poverty aleviation in Nigeria: Lessons from Onelga, Rivers State, Nigeria. American Journal of Social Sciences and Humanities, 1(2): 72-83.

5. Ametorwo, A.M., 2016. Managing work family conflict among female entrepreneurs in Ghana for development. International Journal of Economics, Business and Management Studies, 3(1): 21-35.

6. Amogechukwu, E.T. and C.R. Unoma, 2017. Extent of head teachers utilization of innovative sources of funding primary schools in Enugu State of Nigeria. Journal of Education and e-Learning Research, 4(2): 41-45.Available at: https://doi.org/10.20448/journal.509.2017.42.41.45.

7. Aremu, J.O. and M. Ediagbonya, 2018. Trade and religion in British-Benin relations, 1553-1897. Global Journal of Social Sciences Studies, 4(2): 78-90.Available at: https://doi.org/10.20448/807.4.2.78.90.

8. AyukAko, E.T., 2017. Marlows Dilemma and ours; Conrad and Africas development Agenda: A reading of heart of darkness. International Journal of English Language and Literature Studies, 6(1): 1-10.Available at: https://doi.org/10.18488/journal.23/2017.6.1/23.1.1.10. 
9. Bello, M.Z. and C.U. Aliyu, 2016. Diversification of the nigerian economy for sustainable development: Issues and challenges. International Journal of Economics, Business and Management Studies, 3(2): 75-81.

10. Bilal, Z. and B. Miriam, 2019. Stimulating managerial capital in emerging markets: The impact of business training for young entrepreneurs. World Bank.

11. Bozorgian, H. and S.M. Kanani, 2017. Task repetition on accuracy and fluency: Efl learners'speaking skill. International Journal of English Language and Literature Studies, 6(2): 42-53.

12. Bugu, Z.Y. and H. Yucheng, 2018. An empirical analysis of the factors affecting the profitability of China's agricultural listed companies under the background of agricultural modernization. International Journal of Applied Economics, Finance and Accounting, 2(1): 19-26.

13. Davis, M.K., 2013. Entrepreneurship: An islamic perspective. International Journal of Entrepreneurship and Small Business, 20(1): 63-69.

14. Dierker, L., J.R. Evia, K. Singer-Freeman, K. Woods, J. Zupkus, A. Arnholt, E.G. Moliski, N.D. Deckard, K. Gallagher and J. Rose, 2018. Project-based learning in introductory statistics: Comparing course experiences and predicting positive outcomes for students from diverse educational settings. International Journal of Educational Technology and Learning, 3(2): 52-64.

15. Donkor, A.K. and B.I. Waek, 2018. Community involvement and teacher attendance in basic schools: The case of East Mamprusi District in Ghana. International Journal of Education and Practice, 6(2): 50-63.

16. Elfakhani, S. and Z.U. Ahmed, 2013. Philosophical basis of entrepreneurship principles within an islamic ethical framework. Journal of Transnational Management, 18(1): 52-78.Available at: https://doi.org/10.1080/15475778.2013.752780.

17. Essien, J.M., B.D. Gbeghe, H.N. Kpunee and N. Piabari, 2016. E-marketing products and financial inclusion in Nigeria. International Journal of Economics, Business and Management Studies, 3(1): 47-54.

18. Faizal, P.R.M., A.A.M. Ridhwan and A.W. Kalsom, 2013. The entrepreneurs Said business school of Oxford.

19. Gamba, F.J., 2017. Social capital in selected business associations of food processing SMEs in Tanzania and Rwanda: A synthetic-based approach. International Journal of Asian Social Science, 7(1): 63-84.

20. Gisore, N. and I. Jepchumba, 2017. Effect of budget defict on private investment in East African community for the period 1981-2015: A panel data analysis. International Journal of Business, 4(1): 26-37.Available at: https://doi.org/10.18488/journal.62.2017.42.26.37.

21. Gümüsay, A.A., n.d. Entrepreneurship from an islamic perspective. Said Business School of Oxford.

22. Hoque, N., A. Mamun and A.M.A. Mamun, 2014. Dynamics and traits of entrepreneurship: An Islamic Approach. World Journal of Entrepreneurship, Management and Sustainable Development, 10(2): 128-142.Available at: https://doi.org/10.1108/wjemsd-04-2013-0027.

23. Ramadani, V., L.-P. Dana, V. Ratten and S. Tahiri, 2015. The context of Islamic entrepreneurship and business: Concept, principles and perspectives. International Journal of Business and Globalisation, 15(3): 244-261.Available at: https://doi.org/10.1504/ijbg.2015.071906.

24. Sandra, W.P. and S.A. Vidya, 2018. Academic contrapower harassment (ACPH), and pedagogy for mental health through self-compassion: A conceptual paper. International Journal of Innovation, Creativity and Change, 4(3): 65-80.

25. Sokyna, M.A.-Q. and M.A. Omayma, 2018. Exploring the use of light and colour to detract and enhance the plot of 3D rendered scenes. International Journal of Innovation, Creativity and Change, 4(1): 74-94.

26. Ullah, M.M., B.M. Taskina and Y. Fatema, 2015. Women entrepreneurship: Islamic perspective. International Journal of Islamic Management and Business(1): 1. 